\title{
Interrogating whiteness: A precarious cross-cultural/racial creative writing PhD journey
}

\begin{abstract}
This article explores my coming-to-consciousness and dismantling of whiteness - of white privilege and power - in my self and in my writing during my Creative Writing PhD candidature. Throughout the course of my PhD, I embarked on a cross-cultural/racial project, which involved myself, as a white writer, grappling with the ethical uncertainties of writing about African Australians and of placing the (white) self into the racial problem. Initially, my enquiry began by exploring ways in which I might convey an accurate and dynamic picture of African Australians in my creative work; however, as I progressed in my candidature, and as I tried to find an ethical balance for representing the intercultural/racial encounters between my black African and white Australian characters, questions about the "other" turned to an interrogation of the "self". Had I been reflecting, albeit unconsciously, my ingrained whiteness in my PhD novella? And how might I fracture whiteness in my writing (and in my self) in an attempt to establish a writing position that interrupts my unconscious acts of narrativising whiteness?

Key words: whiteness studies, creative processes, cross-cultural/racial writing
\end{abstract}

From a personal stance of a white writer writing black African and white Australian fictional characters, this article aims to interrogate and fracture whiteness and the role it plays in the cross-cultural/racial writing process. The literature argues that whiteness is an invisible position, existing beyond categories of "race." In Australia, the context from which I write, debates "around native title, reconciliation and immigration demonstrate that "race" is reserved for those deemed to be "other" and as a result "whites as a racial group remain invisible' (McKay 1999: 3). Moreton-Robinson highlights that:

white people in Australian society are not coerced into or required to have a consciousness of, or to define what is, their culture...It remains invisible and unnamed, but familiar and common. White cultural values are taught to children, not as if they were alternatives from which to choose, but as the right and only values. (Moreton-Robinson 1999: 30)

This leads to the assumption that white ways of thinking, seeing and being are "normal" and are the benchmark for all other racially marked ways of being. Dyer argues that 'as long as race is something only applied to non-white peoples, as long as white people are not racially seen and named, they/we 
function as a human norm. Other people are raced, we are just people' (Dyer 1997: 1). Dyer continues by showing the power that comes from associating whiteness with normality: 'the equation of being white with being humansecures a position of power ... White people set the standards of humanity by which they are bound to succeed and others bound to fail' (1997: 9). Because of the power that comes from being white, whiteness is resistant to and discourages being questioned: 'Whiteness, it is argued, has been resistant to analysis precisely because its reproduction maintains a system of authority, privilege and entitlement, in which white subjects and power structures are heavily invested' (Brewster 2009: 130).

It is from this purview - of whiteness as invisible and as associated with privilege and power - that I investigate how whiteness informs my knowledge production and creative practice. To expose whiteness is crucial to critical whiteness studies and 'is a necessary stage, for without visibility there is no way of marking the responsibility for white people to acknowledge the fact of their privilege' (Donald 2000: 158). Homi Bhabha argues that "seeing" and acknowledging whiteness will work towards displacing "the normativity of the white position' as it unmasks it 'as a strategy of authority rather than an authentic or essential "identity"' or way of knowing (Bhabha 1998: 21). As Alison Ravenscroft highlights:

Within prevailing discourses of race, whiteness operates as a cultural ideal, it can therefore never be secured ... We might say, then, that there is no one who can stand in the place of whiteness, there are only subjects who fantasise themselves as being there. (Ravenscroft 2007)

By making visible and theorising the impact whiteness has on my craft, I hope to extricate myself from the holds of unconscious whiteness which I had been writing through. In light of this enquiry, I draw upon Katrina Schlunke's call for white writers to interrogate their whiteness in order to establish a writing position whereby they can expose and deconstruct whiteness, rather than unthinkingly project whiteness in their writing:

it is important to go on showing at what particular moments something called whiteness is able to appear ... and at what moments we might stop writing our own reflections [of whiteness]. But the narrator, the writer of such events, has also to acknowledge their own fractured and flawed self that lets them write such a story. Only when we question the epistemological basis of what constitutes knowledge and the ontological basis of what lets us write knowledge will the writing position be established that can actually fracture [whiteness] rather than become [whiteness]. (Schlunke 1999: 179)

In an attempt to establish such a writing position, I strive to make visible and theorise my own whiteness and the way it informs my knowledge/creative production by drawing on a trip to Kenya and my subsequent PhD journey.

\section{Feeling white, but not yet seeing whiteness [1]}

In 2007, six months before I commenced my $\mathrm{PhD}$, I spent four-months doing volunteer teaching in Ukwala, a remote village in Kenya. It may sound cliché, but I returned home from Kenya "changed". To put my finger on just how I had been "changed" - how the "I" had been shifted, partially re-made - however 
was quite a difficult task. I don't think it was in the romantic way alluded to by the travel brochures: Go to Africa and find yourself. My shift in self was a much more uncomfortable, at times confusing one, more of a 'disidentification from what appears to be' (Frankenberg 1996: 3).

After growing up and living in Tasmania, where the majority of the population is white, for twenty-three years of my life, my arrival in Kenya was more than a cultural-shock; it was a racial-shock. Suddenly I was the odd one out with my pale skin and wispy hair. I was the foreigner, the different one. My initial reaction, surrounded by all those black bodies, was fear; a classic white reaction 'to any intrusion into our cultural capsule' (Howard 1999: 11). This was one of the few times I had felt starkly white.

At first, I thought my initial feeling of being white was simply a physical thing, attributed to the obvious visibility of my pale skin. But it took only a few hours in the hustle and bustle of Nairobi, where I was swarmed by street kids and matatu [2] drivers demanding my money, where I was proposed to by a Kenyan man I had only known for thirty minutes, where I was dropped off at a ritzy hotel where "almost-all" the guests were white (or close to) and all the workers were black, that I realised, viscerally, that this feeling of being white went deeper than the skin. Having a white complexion, as Dyer suggests, meant that I also had a 'passport to privilege,' power and wealth (Dyer 1997: 44, 52). Moreton-Robinson is quick to clarify that whiteness is not only 'found in societies inhabited and dominated by white people ... Whiteness is not just about bodies and skin colour' (Moreton-Robinson 2004: 78). Whiteness instead 'is more about the discursive practices that, because of colonialism and neocolonialism, privilege and sustain global dominance of white imperial subjects and Eurocentric views' (Shome 1999: 108).

I personally witnessed the privileging of white discourses and of white subjects in the predominantly black independent country of Kenya. As I witnessed the empowerment of whiteness, an empowerment that I as a white subject am complicit with, I also became riddled with feelings of guilt and confusion over my privileged status. It was through my physical and social encounters with the Kenyan people, that I began to see my taken-for-granted privilege which was (is) so insidiously part of my white identity. As an effect of this, my white subject-position began to shift. As Slater argues, 'one's self is composed from encounters with otherness ... The image of subjectivity is not one of selfconsistency or fixity, but rather of fluidity and porosity' (Slater 2005: 149). It should be noted, however, that my feeling of being white and seeing my privilege at this time was not yet cognitively associated with race but rather with having grown up in a Western developed country which I thought my pale complexion signified. Moreton-Robinson argues that in most postcolonial work, the racially ambiguous term "the West" is used, wrongly, in the place of the racial construction of whiteness; 'glossed as "the West", whiteness remains invisible, unnamed and unmarked' (Moreton-Robinson 2004: 79-80).

I was of course sad to leave Kenya. I knew I would miss the people that I had met, both from Kenya and from other countries around the world, and that I would miss the richness and diversity of the African culture. On the other hand, I was also privately relieved as I thought my return to the "developed world" would rid the unsettled thoughts - the unsettled "I" - from my mind, that I would lose my white skin and my privilege (and along with them, my guilt and confusion) in the whiteness and Westernness of Tasmania once again.

Frankenberg states that in parts of the world dominated by white bodies, 'race privilege is the (non)experience of not being slapped in the face ... a privilege enjoyed but not acknowledged, a reality lived in but unknown' (Frankenberg 1996: 4). Retreating from ruminating and speaking about how the self had been 
challenged in Kenya (for one, it was both uncomfortable and off-putting to do so, for another, I couldn't quite put into words just how the "I" had shifted - it was also easy back home to feign forgetfulness that it had), I turned to ruminating and speaking of the other, telling and re-telling stories of the people I had met and heard of in Kenya, stories that shocked my listeners, brought them to tears, made them gasp, laugh, tsk with distant sympathy. Had I begun fetishising the African people in an attempt to dissolve my "self"? Or had this act always been part of my white ontology? Moreton-Robinson states that 'the development of a white person's identity requires that they be defined against other "less than human" beings whose presence enables and reinforces their superiority' (Moreton-Robinson 2004: 76). Had I only just begun noticing my participation in something that "didn't-quite-feel-right" because I had begun noticing the self, the not-yet white self, but a self that was not as it had appeared to be?

After such an experience, as much as one tries the self can never return to its original site (Brewster 2005).

Six months after I came home from Kenya, I enrolled in a creative writing doctorate. I would write a cross-cultural novella that would indirectly explore some of my own experiences in Kenya through the intersecting lives of my African and Australian characters. I was still caught up in the buzz (in the fetishising?) of telling stories about Africa; the guilt of my privilege and my implication in neo-colonialism was also still there, however, niggling away at the self. So after doing some preliminary research into postcolonial theory, I decided to write a novella that would capture the "real stuff" of Africans both in Africa and in Australia, not those stereotypical stories - I would debunk those stereotypes, I'd go "postcolonial", create "hybrid" characters and complicate dichotomies of race relations between Westerners and Africans. Ultimately through my more "empathetic" and more "accurately sound" representations I would "do good" by the other. So I set off writing the novella over the next year or so, "doing good" with my pen, perhaps, unconsciously, in a double-bind attempt to redeem my white self from the privilege I had enacted in Kenya (that I was still enacting at that very moment; that I'm still enacting now?), a way to rid myself of guilt. However as Frankenberg bluntly puts it, moving towards 'a narrative deployment of Others in such a way as to secure one's own "redemption" ... [is] a "wrong turn", taken frequently by antiracists and self-analysts of whiteness' (Frankenberg 1996: 6).

Perhaps I began to be aware (albeit indirectly) of this 'wrong turn' by the anxieties that arose as I wrote my African characters. Was I competent to accurately portray African Australians in my fictional work? What if I did something wrong, something that would harm their cultural identity, such as perpetuate stereotypes or misrepresent an element of their cultural beliefs or practices 'through the lens of white supremacy' (hooks 1992: 1)? Ethically, considering the historical negative representations of Africans by whites (and of Indigenous Australians by whites in the Australian context from which I write) should I even be allowed to represent the other? Such questions derive from a body of postcolonial scholarly enquiry that was popular in the 1980s and 1990s which explored 'the anxiety and indignity of white theorists “speaking for" their others' (Brewster 2005). Gayatri Spivak's work is central to this field of enquiry, challenging white subjects to interrogate their own historical subject positions rather than avoiding an engagement with the other. White people, Spivak argues, must

develop a certain degree of rage against the history that has written such an abject script for you that you are silenced...Then you begin to investigate what it is that silences 
you, rather than take this very deterministic position - since my skin colour is this, since my sex is this, I cannot speak. I call these things, as you know, somewhat derisively, chromatism: basing everything on skin colour - I am white, I can't speak... To say "I won't criticise" is salving your conscience, and allowing you not to do any homework. (Spivak 1990: 62-3)

Accepting Spivak's challenge, I began to investigate why I was filled with anxiety about writing African Australians in my work by tracing the way Africans have been negatively represented in the past through white colonial literature, and how African Australians continue to be misrepresented in contemporary white centred mainstream Australian media. I also explored current debates of white writing other (the Indigenous and the migrant other) in Australia, and considered sources such as the Australia Council for the Arts' 'Protocols for producing Indigenous Australian writing' (Janke 2002) to determine my position as a white writer writing the African Australian other. During this enquiry, I also interviewed fourteen ethnic Africans residing in Australia regarding their culture and experiences as Africans in Australia. While pertinent to this topic of white cross-cultural/racial writing, these questions are beyond the scope of this article, which places its focus on the white self, and as such will be explored in another paper.

While these questions were still concerned with representing the other, they worked to once again knock the "I" off its white benign perch by forcing me to analyse the present implications of white writing black, which through the course of my research, including my discovery of whiteness studies, lead me to question not only my representations of the other, but also to question my representations of the self - of my whiteness.

\section{Exposing whiteness in my PhD novella}

After over a year of working on the exegesis I turned again to the novella-inprogress (which had been quietly, though not statically, occupying the backseat of my PhD working space) in order to re-read and analyse the text to see whether I had been unthinkingly projecting my ingrained reflections of whiteness onto my characters and themes. Ravenscroft offers a useful analysis of the effects reading can have on a subject's whiteness:

Reading can shift the whiteness of this subject, however infinitesimally... This is ... to describe a process whereby a reader sees differently rather than sees more... This reader, rather than simply acquiring more knowledge, may need to give up some of the "objects of knowledge" she had previously held onto so dearly. (Ravenscroft 2007)

By re-reading my novella I not only came to see the workings of whiteness in my creative practice, but I was also pressured to "give up" some of my "white ideals" that had been so unquestionably part of my reality. This process is part of the re-drafting of the novella, but it's also a process of re-drafting the self, of re-writing my self out of "unassumed" whiteness so that I can take charge over my representational practices rather than blindly write through the gauze of whiteness. As Gordimer states: 'If the white artist is to break out of [her] double alienation, [she] too has to recognise a false consciousness within [herself], [she] too has to discard [her] white-based value-system' (Gordimer 2010: 308) which is an integral part of her unconscious ontology and informs her knowledge production (Moreton-Robinson 2004: 78). 
It should be noted that it is beyond the scope of this paper to look at all the ways I had been writing whiteness in the earlier versions of my novella (such as feeding on African stereotypes in character and in setting, as well as my presumptuousness in meddling in African cultural aspects that I have very little knowledge about, and of white fetishisings of the other). As such, I have decided to look at how I had been enacting the invisibility of whiteness through the white Australian protagonist, Avie, and the detrimental impact this had on the development of one of the other main characters, Akinyi, a sixteen-year-old girl of Kenyan and Anglo-Australian descent.

Firstly, let me give you a (very brief) synopsis of the earlier version of these two characters and their stories. Upon the discovery of Avie's father's illegitimate daughter Akinyi, Avie and her parents go to Kenya to "collect" Akinyi, whose Kenyan mother has passed away, and bring her "home" to Tasmania. While in Kenya, Avie finds out about her own kept-secret adoption which sends her sense of self spiralling and which mysteriously results in her contraction of psoriasis, a motif reflecting her "shedding" identity. The story continues back in Tasmania as Avie struggles to cope with the knowledge of her adoption and with her severe skin condition, and also as Akinyi tries to come to terms with the death of her mother and with her new existence in a white family in a white town.

It is interesting, and rather disturbing, to note that while I set out to write my cross-cultural/racial novella with the vague intention of complicating racial dichotomies, and while there are numerous opportunities in this storyline where the construction of race could have been exposed and destabilised, whiteness, as it so characteristically does, remained invisible (Ahmed 2007: 261). In fact, race - or at least "blackness" - was only superficially explored through the coloured character Akinyi (I had perhaps only two chapters devoted to Akinyi's experience of being "black" in Tasmania, and a couple more where Avie reflects on Akinyi's racial makeup). This brings up two important points for my discussion. One is the way in which representations of the other are more often subverted in, for example, white postcolonial writing, while whiteness remains unnamed and unmarked. Moreton-Robinson confirms this premise:

Techniques through which other racial categories are deconstructed, reconfigured, subverted and changed, elided and embedded, have not been applied to whiteness...this ensures that race continues to belong to the...other and whiteness remains hidden. (Moreton-Robinson 2002: 82)

The second point is that race (or at least the construction of blackness) was only superficially explored, which upon reflection I think had something to do with Avie's storyline of her adoption and psoriasis. Originally, one of the reasons, among many, that Avie's character was given the elements of her adoption and psoriasis was so that she could to some degree empathise with and experience just a little of Akinyi's own sense of dislocation and destabilisation of self that derived from being uprooted from Kenya and placed in an unfamiliar (white) family and community. Avie's peeling skin, its outward "difference", and the discrimination she felt because of it, was also used as a way to promote understanding of Akinyi's own experience of racial difference. It's difficult to say whether these elements of Avie's character emerged consciously or unconsciously; as Baranay says, 'writing fiction makes discovery and invention feel like the same thing' (Baranay 2002: 151). I explore Baranay's statement further on. But what is important to note here is that my attempts to explore a sense of displacement between my two characters by likening Avie's adoption and psoriasis to Akinyi's racial makeup was a wrong turn to make in trying to undermine (or even to understand) 
constructions of race. Avie's experience of displacement had nothing to do with race, while Akinyi's had everything to do with it, which only further masks whiteness and its marginalising effects on non-white people. Furthermore, Probyn argues that 'ressentiment (weakness) supplied by other subject positions' (for Avie such ressentiment derives from her adoption and psoriasis) also fails to tackle whiteness as it re-contextualises the white subject 'in more palatable (less privileged) terms', making the white subject appear to be on a similar "marginalised" level to the other (Probyn 2007: 332). I should have instead conveyed through my white and black characters that 'the order of [one's] experience as a white ... differ[s] completely from the order of black experience' and examined why this is so (Gordimer 2010: 308).

To compound my dismal (white) attempts to explore constructions of race by using Avie's adoption and psoriasis as tools to understand blackness, Avie's angst over her adoption and skin condition had begun to metamorphose and take over the novella. Not only did this thwart any further interrogation of race relations, but it also seriously crippled the development of Akinyi's character. While Avie's character acquired considerable depth through my preoccupation with her story, Akinyi's character diminished to a superfluous two-dimensional character lurking in Avie's shadow. I realise now that Akinyi had become an "object" in the novella-in-progress, existing only to enrich my narrative with an exotic flavour. Through my representations, I had perpetuated white supremacist ideology that constructs the assumption that 'the dominant White culture merely and unquestionably exists' while 'migrant cultures exist for the latter' (Hage 1998: 121). In my intentions to complicate racial dichotomies I had only reinforced them.

\section{Kate Grenville and The Secret River}

I'd like to divert from my novella, for a moment, and turn to Kate Grenville and her journey in writing The Secret River (2005), a cross-cultural/racial novel which 'reassess[es] what it means to be a white Australian' (Wyndham 2006). Grenville's experiences of writing this novel exemplify the role whiteness plays in deflecting an interrogation of itself in a white writer's creative work. Examining Grenville's writing journey is also useful as it provides a model for how I might continue with my own novella differently in a way that interrogates racial constructs rather than deviates from them and, more importantly, in a way that I might be able to destabilise whiteness rather than unthinkingly narrativise it.

Grenville was first driven to write The Secret River (2005) on the day of the Sydney Harbour Bridge walk for Aboriginal Reconciliation. This event, held on May 28 2000, saw over 300,000 people from many different races and backgrounds walk across the iconic Sydney Harbour Bridge in an effort to show support for Indigenous Australians after hundreds of years of discrimination. The primary aim of the event was to promote reconciliation between Aboriginal and Torres Strait Islander peoples and the broader Australian community. Grenville recounts that during the walk she made eye contact with an Indigenous woman and shared 'one of those moments of intensity ... we smiled, held each other's gaze' until 'it sent a sudden blade of cold into my warm inner glow' (Grenville 2006: 12). Like my experiences in Kenya articulated earlier, this interracial encounter caused Grenville to undergo a shift in white subject-position, unsettling, perhaps unconsciously, her own whiteness. Immediately she knew that what she was doing on the bridge was inextricably connected to her settler ancestor Solomon Wiseman - 'In that instant of putting my own ancestor together with this woman's ancestor, 
everything swivelled: the country, the place, my sense of myself in it' (Grenville 2006: 13) - and she realised that she urgently needed to know what her great-great-great grandfather

might have done when he crossed paths with Aboriginal people... Until I knew that, it felt like nothing but wilful blindness - even hypocrisy - to go through the symbolic motions [of a walk on the bridge] ... what I had to do was cross the hard way, through the deep water of our history. (Grenville 2006: 13)

Grenville's investigation into her family's settler past, and her interrogation of 'what white sovereignty does to Indigenous rights' (Nicoll 2004: 19), inevitably leads her to a recognition of her own white "false consciousness." In her writing memoir Searching for the Secret River (2006), Grenville says that as she researched into the past and into Aboriginal culture, she realised 'how blindly I'd been embedded in my own culture. I'd never recognised it as a culture - a learned thing' (Grenville 2006: 129). Adam Gall highlights that as Grenville moves "from one side of the frontier, to the "other side"" during her research and reflections into the past, her identity as a "contemporary liberal settler subject' becomes 'defined and redefined' (Gall 2008: 95). However, what is interesting about this process is that even though Grenville experiences a shift in her white subject-position, she does not become immune to "white" thoughts that come reflexively and unbidden. As I will soon show, this is significant in regards to her own impulsive projections of whiteness that arise when she begins writing her novel. This persistent nature of her whiteness is exposed when she first encounters people of unmixed Aboriginal descent in the Kimberley. Having never known or even seen anyone like the Aboriginal characters she was describing in her novel, Grenville went to the Kimberley to observe the Aboriginal people there. Overhearing them talk in their Indigenous tongue, Grenville's first (white) thought was 'they're speaking a foreign language' (2006: 194). Having undergone a destabilisation of whiteness, she quickly realised:

No...It's me. I'm the one speaking the foreign language.

I was ashamed. My first reaction had been to think they were the foreigners. That was how backward I was, underneath those fine sentiments. In spite of my good intentions and highminded thoughts, I didn't understand a thing. (Grenville 2006: 194)

Grenville's experience illuminates just how difficult it is to untangle ourselves from the pervasive invisibility of whiteness that is so much a part of the white subject's subconsciousness and offers some insight into the workings of whiteness in a white writer's creative work, which I would like to tease out now.

Although Grenville intended to explore the white settler/Indigenous encounter on the Hawkesbury River, when she came to writing her book she gradually drifted from her original aim. After years of researching and writing her manuscript, she sat back to read the text from start to finish only to find that there were two separate stories unfolding on the Hawkesbury River unceremoniously competing with each other: 'One was a story about settlement - Wiseman and his family and their relationship with the Aboriginal people. The other was a classic revenge-and-romance story' based on Wiseman's love affair with his childhood sweetheart Sophia (Grenville 2006: 181). 'The first was a sombre story based on real, tragic events. The second was a lightweight, contrived thing' (Grenville 2006: 181) and threatened to overshadow and make 
light of the real issue at hand: that of the 'the morphology of colonialism' and its poisonous effects on the Indigenous inhabitants of Australia, and how it continues to 'persist in discursive and cultural practices' today (MoretonRobinson 2002: 24).

Finding no 'way to knit [the two stories] together' (Grenville 2006: 178), Grenville eventually realised, after a moment of insight, that she had to cut the 'romance-and-revenge' story out:

Straight away it was as if chains had dropped off the story. The Wisemans and the Aboriginal people were left alone to get on with it ... It was just the two of them, working it out together, and that was what the story was. White meeting black, black meeting white, and everyone trying to decide what to do. (Grenville 2006: 181-3)

By 'everyone', I think it would be safe to assume, Grenville is not just talking about her characters of the past, but also about herself and what she must do was doing through the writing of her novel - to understand and acknowledge what white sovereignty did and continues to do to Indigenous rights. The 'chains' (of whiteness?) had 'dropped' from Grenville, allowing her to meet face-to-face with her insidious white colonial past and neo-colonial present.

The meandering, round-about way in which Grenville wrote her novel could be seen as the creative mind simply (or not so simply!) doing its job by 'let[ting] the writing go where it will' (Brophy 1998: 198). Many writers speak of this organic process. For example, Helen Garner, when beginning a novel, says, 'I never have a theoretical idea for a book. What I write ... emerges organically ... I try it this way and I try it that way ... at any given moment I don't know where I'm going' (Grenville \& Woolfe 1993: 61, 64). Isabel Allende also says that when she writes a book the story unfolds 'itself, slowly, in a long process. By the time I've finished the first draft I know what the book is about. But not before' (Epel 1993: 8). I don't wish to argue here against the organic nature of the creative process, rather I want to suggest that perhaps this elusive, unconscious part of creativity may be, among other things, implicated with and feeds on that unconscious ontology of the white cross-cultural/racial writer's whiteness [3].

I suggested earlier that as whiteness inhabits the white subject's unconscious mind, it must play a part in the white writer's creative output. Considering, then, that whiteness is also 'resistant to analysis' (Brewster 2009: 130) and that white race privilege discourages an interrogation of whiteness (Nicoll 2004: 30 ), would it be so far off the mark to wonder if Grenville's lightweight 'romance-and-revenge' thread which threatened to supersede (to colonise) the settler/Indigenous story in her novel, was perhaps an unconscious white defence mechanism, an accomplice with whiteness, stalling the author and her characters from tackling head on the poisonous effects of their own whiteness? Was following the 'romance-and-revenge' story 'a kind of deflection away from [her] own complicity' (Probyn 2007: 339) in the impact that whiteness has on Indigenous people, a complicity which is painful, confronting and challenging to the white subject's privilege, power and sense of self?

\section{Dropping the "chains" from my own novella}

In questioning Grenville's writing of The Secret River, I must turn back to question my own novella-in-progress. Like Grenville's 'romance-and-revenge' story, I had also let Avie's adoption and psoriasis narrative supersede an 
interrogation of racial constructions; not only did this further mask whiteness but it also perpetuated racial dichotomies through my poorly nuanced Kenyan character Akinyi. I had deflected away from my own complicity in the race problem, I had avoided (albeit unconsciously) coming face-to-face, through my characters [4], with the impact my whiteness has on non-white people. After learning about Grenville's own struggles in writing The Secret River, and after having researched critical whiteness studies and incorporating it into my critical discussion on white representations of African Australians, it became clear, finally, what I had to do. I must kill off Avie's adoption, release her from her overdramatic and blinding angst, and let Akinyi out of the shadows. It was clear that if the central story - Avie's story - could be told without an African character, then having Akinyi in the novella was in many ways ethically problematic. While it would have been easier - aesthetically, ethically, politically - to cut Akinyi out, free her from the oppressive hand of whiteness and focus the novella solely on the complexities of adoption, I would have been, once again, exercising another 'form of White privilege' by turning away from my whiteness rather than looking, scrutinizing and destabilising it (Howard 1999: 21).

It was about the same time that I cut the adoption narrative out, and only after I had struggled blindly in the early writing of the characters and their story, coupled with the long and difficult process of recognising and interrogating my whiteness in my exegesis, that I also realised the significance of the motif of Avie's peeling skin. It seems that it is not until we have experienced 'a high degree of difficulty and frustration' that 'the most intense insights' come to us (Woolfe 2007: 50). The motif was about whiteness: Avie's and her parents' whiteness, my whiteness, an exposing and undermining of "assumed" whiteness pressured to the surface by Akinyi and the other African characters in the novella. It was so blatantly obvious now, embarrassingly obvious. I guess I had just been so blinded by my own white race - it is 'invisible for those who inhabit it' (Ahmed 2007: 261) - that I had failed to see the thematic principle of undermining whiteness in Avie's shedding skin that had been there all along.

But how and why did this thematic principle of undermining whiteness emerge within my writing despite my not intending it and, more puzzling, despite whiteness being suppressed from my consciousness at the time that the motif of Avie's psoriasis emerged? In Mystery of the Cleaning Lady (2007), Woolfe explores a similar question to my own when she tries to find out how writers can create a fictional work of thematic coherence if they write without intending this or that theme. During her exploration she comes across the idea of "themata", or "gut" assumptions, which act 'as the guiding, visionary elements leading to creativity' (Woolfe 2007: 99). Woolfe contends that themata 'emerge of their own accord, in their own time', however they are implicit in the writing, 'they inherently belong to the work, to what has already been written' (2007: 100). Baranay also considers the way in which certain elements emerge organically and unintentionally in one's writing when she discusses the development of her character Pandora in Neem Dreams. Although Pandora's character transformed dramatically over time, Baranay contends that there were certain aspects about Pandora which remained unchanged: 'Those initial and unchanging elements of this character arise from impenetrable depths of the unconscious... and from these givens much has to be discovered, or invented' (Baranay 2002: 151).

Three things stand out to me in Woolfe's and Baranay's statements which are important to this discussion: one, that there is always a thema, most often implicit in the beginning, guiding a creative work; two, that these themata - or important elements in the writing that personify the themata - arise from the unconscious (and will themselves to stay); and three, that what these 
themata/motifs mean is not always apparent when they first appear, but becomes evident through the writing process (for my project, I include in this process the dialogic writing of the novella and the exegesis). As suggested above, the thematic principle - the themata - in my novella became an exploration and undermining of assumed whiteness symbolised through the initial motif of Avie's peeling skin - a peeling away of blind whiteness, a peeling away of self as one knows it, a peeling away of whiteness itself. The motif was always there, brought up from the unconscious, its significance waiting to be discovered along the way.

Johnson argues that 'through metaphor, we make use of patterns that obtain in our physical experience to organize our more abstract understanding' (Johnson 1987: xv). In retrospect, it is no surprise, considering the concentrated embodied intercultural/racial experiences I had in Kenya, and the acute awareness and rumination of the colour and symbolic meaning of my skin which followed these experiences, that the metaphor of Avie's own peeling skin appeared very early in my writing. In fact, this metaphor was evident in the very first penned sentences of my first draft, as can be seen here: 'This pen will save me it will. I rub it between my fingertips and a film of skin rolls off onto its plastic covering. "Willow, my skin, its shedding off!"” (Bellette 2008). But what is intriguing with this image of the peeling skin is that it brought about the element of Avie's adoption. I thought that Avie's shedding skin, then, symbolically reflected the "shedding" of her identity that came about after the revelation of her adoption, not, as one would expect after my experiences in Kenya, a "shedding" of self caused by Avie's intercultural encounters with the other African characters.

Upon reflection, I think it is reasonable to assume that the adoption narrative spuriously stemmed from my first memories [5] of "blackness": of my two aunties who are both coloured and adopted, of the stories told by my mum in a tone of taboo about the time her sisters were spat on at school, the names that stung - 'dirty nigger', 'blackie'; of the time she found one of her sisters tucked up in bed, asleep and dusted thick with talcum powder because she hoped to wake up white like mummy. These haunting second-hand memories are ones that visit my conscious mind unbidden and quite often, and were certainly present during the writing of the earlier drafts of the novella. Perhaps unconsciously, through the adoption narrative, I was in fact trying to explore and understand something about race; perhaps unconsciously I was trying to subvert the usual black adoption narrative, and the white power and privilege that is enacted in such a narrative, which is so common in the white imagination about Africa, by attributing the adoption narrative to my white character. At the same time, however, I failed to fully investigate the racial issues that were circulating in my original memories, just as I failed to subvert ideas of white power and privilege enacted in the adoption narrative. It was as if my creative unconscious mind, since the shift in the "I" that occurred in Kenya, had become both an accomplice with, and mutineer against, whiteness; it was both unaware and aware of my whiteness, or perhaps it was always aware yet suppressing that awareness. Nicoll describes this tension as the 'mental gymnastics of unconscious whiteness' (Nicoll 2000: 382) which occurs in the white liberal subject who is sympathetic towards the other yet is still in denial about their whiteness. This idea of the 'mental gymnastics of unconscious whiteness' coincides with my previous ruminations of the unconscious part of creativity which perpetuates unchallenged assumptions of whiteness ingrained in a white writer's ontology, and with the following suggestion that there is also an unintentional 'thematics' of writing involved in unconscious creativity which can allow for a deconstruction of whiteness to emerge unbidden in cross-cultural/racial writing. Both elements of unconscious creativity are relevant and at play in a white writer's work who is coming-to- 
consciousness of their whiteness. Both elements pull and tug at the white writer, and it is not until the writer re-reads, re-writes and analyses the text at hand (and herself), that the themata of deconstructed whiteness can be realised.

If my speculation into my own creative ideas is correct, I could assume that I was perhaps always already unconsciously aware of my whiteness, that each time my racial identity was shifted - each time my whiteness was fractured through my intercultural/racial encounters (even if I was unconscious of that shift/fracture) I moved that little bit closer to consciously 'seeing' my whiteness. Perhaps, then, this is why the themata of exposing and undermining whiteness which was embodied in the motif of Avie's peeling skin was always already implicitly there in the earlier versions of the novella, waiting to be discovered through the researching and writing of the exegesis and through the further re-writing of the novella itself. As Woolfe suggests, themata, although they come unbidden, 'express the writer's psychological and spiritual relationship with the world' and are not 'known until they're written down. Writing them is knowing them' (Woolfe 2007: 100).

This insight into the way themata emerge in one's writing is powerful evidence for the way in which writing (and extensive re-writing and reflection) brings suppressed thoughts, feelings and beliefs to the surface, and of its transformative and syncretic possibilities. White South African novelist Nadine Gordimer, who for the majority of her life fought against apartheid, bears witness of this when she says that "the "problems" of my country did not set me writing; on the contrary, it was learning to write that sent me falling, falling through the surface of "the South African way of life"" (Gordimer 2010: 119). She characterises her early efforts at writing as a "clumsy battle to chip my way out of shell after shell of ready-made concepts and make my own sense of life' (2010: 120). For Gordimer it was writing that woke her up to her whiteness; that fractured her 'false consciousness'; that led her to unsettling the 'realities' of apartheid and the exploitation of blacks (2010: 308).

\section{Conclusion}

Although I'm wary of likening myself to Gordimer, the Nobel Literature prizewinner and ardent political activist, I do feel that through the dialogical process of writing between the exegesis and novella, I have in my own naive and clumsy way begun, at least, to chip my way out of my own 'false consciousness' and work towards re-narrativising whiteness in my writing by making it visible and strange rather than unconsciously reflecting it. I have tried to convey this through my theorisations of "feeling white" in Kenya and through my exploration of becoming aware of the ontological basis that was influencing my writing of whiteness in the earlier versions of the novella. I must pause here to question, however, whether through this investigation I have been able to establish a writing position whereby I 'can actually fracture [whiteness] rather than become' whiteness (Schlunke 1999: 179). Can I cease 'becoming' white simply by exposing and re-narrativising whiteness in my writing? Here, this query puts into question Gordimer's earlier call for a white artist to discard her 'white-based value-system' in order to recognise her white 'false consciousness' (Gordimer 2010: 308), for what does the white artist replace those values with?

Probyn argues that it is impossible for a white subject to simply discard white values, or in other words, "give up power", through articulating and challenging their whiteness. She argues that: 
there is no "giving up power" without power being taken/transmuted into another form; taking responsibility, taking a good hard look at yourself, taking care, taking part, taking on ressentiment, taking up the challenge, taking time, taking task, taking over. (Probyn 2007: 324)

Probyn's final suggestion, 'taking over', with its connotations to white supremacy, is particularly unsettling, for however one tries to fracture whiteness, one is still inside the position of power and privilege enacted by whiteness. Ahmed also shows the difficulty of undoing social hierarchies 'once we have "seen through them"... Race, like sex, is sticky; it sticks to us, or we become "us" as an effect of how it sticks, even when we think we are beyond it' (Ahmed 2007: 280). In opposition to Gordimer's call for white artists to discard their whiteness, JM Coetzee argues that perhaps all a white writer can do is trace his limitations and complicity with his white representations of the other; to be constantly haunted by one's 'position of power, pen in hand' (Morphet 1987: 461-62).

It is clear that 'we do not yet have a language to challenge privilege from within privilege' (Probyn 2007: 330). But this does not mean that we should stop trying, even in our clumsy attempts, to find that language, nor should we stop trying to persistently interrupt our narrativisations of whiteness (Brewster 2005). As Ahmed argues, we need to begin to live with the 'stickiness' of race: 'To think it, feel it, do it, is about creating a space to deal with the effects of racism. We need to deal with the effects of racism in a way that is better' (Ahmed 2007: 280).

Ahmed suggests whiteness studies must involve a 'double turn' if it is to clear some ground 'upon which the work of exposing racism might provide the conditions for another kind of work' - a work which can better deal with the effects of racism (2007: 284). This 'double turn' would involve whiteness studies turning

towards and away from those bodies who have been afforded agency and mobility by such privilege. In other words, the task for white subjects would be to stay implicated in what they critique, but in turning towards their role and responsibility in these histories of racism, as histories of the present, to turn away from themselves, and towards others. (Ahmed 2007: 284)

In a progressive fashion, my focus shifted during my $\mathrm{PhD}$ research from the African Australian to the white Australian self, driven by the ethical imperative, as a white cross-cultural/racial writer representing Africans in her fictional work, to respond to the long historical dominance of Africans by white supremacy, a domination which continues neo-colonially in the present. Moving the focus from the other to the self has pressured me to locate whiteness - and thus myself as a white subject who inhabits it unavoidably - as the source of racism, and has opened my eyes to the ways in which I had been performing my whiteness (and will continue to do so in transmuted ways) in my writing practices and in my everyday life. Perhaps, however, the 'double turn' that Ahmed calls for in whiteness studies, was enacted foremost in my creative practice as I shifted back and forth between my white Australian and black African Australian characters, re-drafting and re-writing my representations of blackness and whiteness. This shifting back and forth between bodies enabled me to create, I believe, a far better ethically and racially nuanced and balanced piece of writing, as compared to my earlier drafts. On one hand, I was urged to deconstruct misleading portrayals of African Australians in contemporary Australia, aligning my representations 
with the way in which the African Australian interviewees from my research, and other African Australians, wish to be known. On the other hand I was also pressured, constantly, to make visible my white characters' race, renarrativising whiteness alongside the deconstruction of blackness. This imaginative jostling of bodies, of black and white, of self and other, worked to not only shape my characters, but also to re-shape myself. 'Imagining is not merely looking or looking at; nor is it taking oneself intact into the other. It is, for the purposes of the work, becoming' (Morrison 1992: 4).

Was I able to find a writing position whereby I could fracture whiteness rather than unconsciously reflect whiteness? In other words, is my final version of the $\mathrm{PhD}$ novella less 'racist' than earlier versions? Although I cannot avoid performing some form of whiteness, I can refuse 'to go along with certain practices and expectations' of it (Frankenberg 1996: 16) in an effort to better deal with the effects of racism. I hope that in my tentative reflections here in this article which have derived from my doctorate exegesis, as well as in the rewritten version of the $\mathrm{PhD}$ novella which shifted back and forth between bodies, that I have been able to explore the source of racism and its effects in a better (albeit, I will be the first to admit, flawed and insufficient) way than what I could have done before embarking on this project.

\section{Notes}

[1] Subheading adapted from Ruth Frankenberg's personalised critical whiteness article, "When We are Capable of Stopping We Begin to See": Being White, Seeing Whiteness' (1996). Frankenberg's article significantly influenced the shaping of the self-reflection in this section. return to text

[2] A matatu is a mini-bus, the most common public transport in Kenya and in neighbouring countries. return to text

[3] I say 'among other things' in this sentence as I do not want to imply that the spontaneous output of creative writing that comes from the unconscious part of the mind solely reflects a white writer's false constructions of whiteness. Possibilities for counter constructions of whiteness can also emerge unconsciously during organic processes of writing, as I later demonstrate in this article. return to text

[4] Baranay suggests that fictional characters are an extension of the writer's self; as the writer is both the 'creator' and 'manipulator' of the character, the character inevitably adopts the writer's 'own experience - including observation, imagination and fantasy' (Baranay 2002: 144). As such the characters (regardless of their race) would adopt the white writer's own whiteness and her consciousness - or non-consciousness - of her racial identity. return to text

[5] For an examination of the role that spurious memories play in creative ideas see Woolfe (2007: 63-4). return to text

\section{Works Cited}

Ahmed, S 2007 'Declarations of Whiteness: The Non-Performativity of Anti-Racism Performance?', in DW Rigg (ed) Taking Up the Challenge: Critical Race and Whiteness Studies in a Postcolonising Nation, Crawford House Publishing, Adelaide: 261-86 return to text

Baranay, I 2002 Sun Square Moon: An Exegesis With Accompanying Novel: Neem Dreams. $\mathrm{PhD}$, Griffith University, Gold Coast, Queensland return to text

Bellette, F 2008 Fragile Skins - First Draft. [PhD Novella] (unpublished draft of novella, 8 June 2008) return to text 
Bhabha, H 1998 'The White Stuff', Artforum 36, 4: 21-24 return to text

Brewster, A 2005 'Writing Whiteness: The Personal Turn', Australian Humanities Review 35: http://pandora.nla.gov.au.simsrad.net.ocs.mq.edu.au/pan/10116/20051122-0000/www. lib.latrobe.edu.au/AHR/archive/Issue-June-2005/brewster.html (accessed 30 Aug 2010) return to text

Brewster, A 2009 'Beachcombing: A Fossicker's Guide to Whiteness and Indigenous Sovereignty', in H Smith \& R Dean (eds) Practice-Led Research, Research-Led Practice in the Creative Arts, Edinburgh UP, Edinburgh: 126-49 return to text

Brophy, K 1998 Creativity: Psychoanalysis, Surrealism and Creative Writing, Melbourne University Press, Melbourne return to text

Donald, S 2000 'Seeing White: Female Whiteness and the Purity of Children in Australian, Chinese and British Visual Culture', Social Semiotics 10, 2: 157-71 return to text

Dyer, R 1997 White, Routledge, London return to text

Epel, N 1993, Writers Dreaming: Twenty-Six Writers Talk About Their Dreams and the Creative Process, Vintage Books, New York return to text

Frankenberg, R 1996 “"When We are Capable of Stopping We Begin to See"': Being White, Seeing Whiteness', in B Thompson \& S Tyagi (eds) Names We Call Home: Autobiographies on Racial Identity, Routledge, New York: 3-17 return to text

Gall, A 2008 'Taking/Taking Up: Recognition and the Frontier in Grenville's The Secret River', JASAL Special Issue: 94-104:

http://pandora.nla.gov.au.simsrad.net.ocs.mq.edu.au/pan/63067/20090910-

1633/www.nla.gov.au/openpublish/index.php/jasal/article/ view/668/982.html (accessed 28 June 2011) return to text

Gordimer, N 2010 Telling Times: Writing and Living, 1954-2008, WW Norton, New York return to text

Grenville, K 2005 The Secret River, Text Publishing, Melbourne return to text

Grenville, K 2006 Searching For the Secret River, Text Publishing, Melbourne return to text

Grenville, K \& S Woolfe 1993 'Helen Garner - The Children's Bach', in K Grenville \& S Woolfe (eds), Making Stories: How Ten Australian Novels Were Written, Allen \& Unwin, Crows Nest: 59-93 return to text

Hage, G 1998 White Nation: Fantasies of White Supremacy in a Multicultural Society, Pluto Press, Annandale, NSW return to text

hooks, b 1992 Black Looks: Race and Representation, South End Press, Boston return to text

Howard, G 1999 We Can't Teach What We Don't Know: White Teachers, Multiracial Schools, Teacher's College Press, New York return to text

Janke, T 2002 Writing Cultures: Protocols for Producing Indigenous Australian Literature, Aboriginal and Torres Strait Islander Arts Board, Australia Council, Strawberry Hills, NSW return to text

Johnson, M 1987 The Body in the Mind: The Bodily Basis of Meaning, Imagination, and Reason, Chicago University Press, Chicago return to text

McKay, B 1999 'Making Whiteness Visible', in B McKay (ed), Unmasking Whiteness: Race Relations and Reconciliation, Queensland Studies Centre, Nathan, Queensland: 3-6 return to text

Moreton-Robinson, A 1999 'Unmasking Whiteness: A Goori Jondal's Look at Some Duggai Business', in B McKay (ed) Unmasking Whiteness: Race Relations and Reconciliation, Queensland Studies Centre, Nathan: 28-36 return to text

Moreton-Robinson, A 2002 Talkin' Up To The White Woman: Indigenous Women and Feminism, Queensland University Press, St Lucia, Queensland return to text 
Moreton-Robinson, A 2004 'Whiteness, Epistemology and Indigenous Representation', in: A Moreton-Robinson (ed) Whitening Race, Aboriginal Studies Press, Canberra: 75-88 return to text

Morphet, T 1987 'Two Interviews with J.M. Coetzee, 1983 and 1987', Tri-Quarterly 69, Spring-Summer: 454-64 return to text

Morrison, T 1992 Playing in the Dark: Whiteness and the Literary Imagination, Harvard University Press, Cambridge return to text

Nicoll, F 2000 'Indigenous Sovereignty and the Violence of Perspective', Australian Feminist Studies 15, 33: 369-86 return to text

Nicoll, F 2004 'Reconciliation In and Out of Perspective: White Knowing, Seeing, Curating and Being at Home In and Against Indigenous Sovereignty', in A Moreton-Robinson (ed), Whitening Race, Aboriginal Studies Press, Canberra: 17-31 return to text

Probyn, F 2007 'Playing Chicken at the Intersection: The White Critic of Whiteness', in DW Rigg (ed) Taking Up the Challenge: Critical Race and Whiteness Studies in a Postcolonising Nation, Crawford House Publishing, Adelaide: 322-46 return to text

Ravenscroft, A 2007 'Who is the White Subject? Reading, Writing, Whiteness', Australian Humanities Review 42, August return to text

Schlunke, K 1999 'Unsettling Whiteness', in B McKay (ed) Unmasking Whiteness: Race Relations and Reconciliation, Queensland Studies Centre, Nathan, Queensland: 173-79 return to text

Shome, R 1999 'Whiteness and the Politics of Location: Postcolonial reflections', in T Nakayama \& JN Martin (eds) Whiteness: The Communication of Social Identity, Sage, London: $107-28$ return to text

Slater, L 2005 'Kim Scott’s Benang: An Ethics of Uncertainty', JASAL 4: 147-58 return to text

Spivak, G 1990 'Questions of Multiculturalism', in S Harasym (ed) The Post-Colonial Critic: Interviews, Strategies, Dialogues/Gayatri Chakravorty Spivak, Routledge, New York: Routledge: 59-66 return to text

Woolfe, S 2007 The Mystery of the Cleaning Lady, Western Australia University Press, Crawley, Western Australia return to text

Wyndham, S 2006 'River of Champers for Grenville Opus', Sydney Morning Herald (16 September): http://www.smh.com.au/news/books/river-ofchampers-forgrenvilleopus/2006/09/15/1157827 158915.html (accessed 27 June 2011) return to text

Dr Filipa Bellette lives in Tasmania and teaches online Creative Writing for Macquarie University. In 2012, she completed her Creative Writing PhD with Macquarie University, titled 'A White Writer's Ethical Uncertainties: Writing African Australians, Self and Whiteness', reflecting her research interests in cross-cultural/racial writing and its transformative possibilities. She has had a selection of poetry published in literary magazines, including Blue Dog: Australian Poetry. In 2006, she completed her Honours degree at the University of Tasmania, winning the University Medal. She is currently working on her novel titled, 'Fragile Skins', a chapter from which was published in The Quarry. 
Vol 17 No 2 October 2013

http://www.textjournal.com.au

General Editor: Nigel Krauth. Editors: Kevin Brophy \& Enza Gandolfo text@textjournal.com.au 